\title{
FUTURE OF SOCIAL SCIENCES AND HUMANITIES IN CORPORATE UNIVERSITIES: CURRICULA, EXCLUSIONS, INCLUSIONS, AND VOICE ${ }^{1}$
}

\author{
Nimat Hafez Barazangi \\ Cornell University, Women's Studies Program \\ And the Cornell Participatory Action Research Network
}

\section{Institute for European Studies Working Paper, 01.1}

Nimat Hafez Barazangi received several awards for her Action Research, including the Glock Award for her 1988 Ph.D. dissertation, an Oxford University Visiting Fellowship, a Fulbright Scholarship and a UNDP Fellowship. She is a Research Fellow, specializes in Curriculum and Instruction, Islamic and Arabic Studies, and Adult and Community Education.

I wish to acknowledge the discussants at the University Seminar for their invaluable comments. I am especially grateful to Davydd Greenwood for his constructive suggestions and encouragement.

\footnotetext{
${ }^{1}$ Parts of this paper will be presented in the Author's forthcoming book: Women's Self-Identity and the Qur'an (under review).
} 
(C) Nimat Hafez Barazangi, April 2001

This paper should not be reproduced in whole or in part without the prior permission of the author.

All papers published are exact reproductions of the author's text. 


\begin{abstract}
During three preceding sessions of the Institute for European Studies (IES) Topical Seminar, three themes were discussed: (1) The university as a corporation, focusing on faculty involvement and partnership with the corporation and the corporate world beyond the university, (2) the students as inheritors of culture and the university as the means of perpetuating cultural norms, and (3) the economic base of higher education.

In my focus on the curriculum, I am basically looking at the philosophical, ethical, and pedagogical dynamics of all the above elements when mapping and disseminating knowledge. I am also looking at how knowledge itself, a main asset of the university, is manipulated between research, teaching, and learning by the old and new guard of academia.

Though the three essays (Barazangi, 1993; hooks, 1994, Middleton, 1993) being analyzed under the curriculum theme were written for different cases and from different worldviews, they share the same historical context. A time when the New Right movements were back lashing at the different cultural groups, including women, as these groups voiced their concerns about curricular inclusions and exclusions, these reactions were manifested in the multicultural vs. mainstream curricula, in the affirmative action admission and testing practices, and in social welfare policies.

The contemporary context consists, in addition, in recent emphases by funding agencies on educational components in research proposals even by NSF, especially in K-12. Residential learning among college students, is replacing ethnic-based dorms or language houses. Yet, the old philosophy of dichotomized subject matters and fields of studies still prevails in recent discussions of liberal arts curricula. A recent report by the Curriculum Committee of the Cornell College of Arts and Sciences still classifies reasoning skills into quantitative and qualitative, with an add-on of moral reasoning. Furthermore, engagement in learning is mainly still treated as a practical skill for the arts and sciences and not part of their main mission, and so on.
\end{abstract}




\section{Setting the Context}

I should state at the onset of this paper the fact that although I was institutionally trained as a curriculum specialist, a psycholinguist, and was a philosophy major in my undergraduate studies, my remarks on the theme under consideration, the curriculum, cannot be divorced from my self-identity and self-learning with/in the action-oriented philosophy of Islamic education. I am making this statement to set the stage for understanding the interaction of identity and knowledge when designing, implementing, and evaluating a curriculum. So, this discussion is not about including Islamic philosophy of education, feminist education, or black studies in the university curricula. It is, rather, about the forgotten factor in mapping the successes and failures of the social sciences and the humanities curricula--or any other curriculum. The forgotten factor is the inquisitive process that a learner goes through as $\mathrm{s} /$ he attempts to make sense of and to act on the nature of knowledge, its origin, and evolution, with the goal of self-realization as a citizen.

As I read the three essays listed above, a set of questions emerged as follows:

1. How would these three studies help us think about the future of social sciences and the humanities?

2. What was the process that determined the philosophy, methodology and content of these studies?

3. Who were the agents that have generated and disseminated these studies within their respected fields of study?

4. Why do we need an alternative process?

5. Who might be the agents of re-charting and implementing the new course of study, and

6. When it would be possible to claim legitimacy for such a process?

Looking through the eyes of these relatively young fields of study, such as feminist studies and its academic arm, Women's Studies, ethnic and cultural studies, I move, in my discussion, among three spirals, intertwined levels: (a) social structure and its dynamics of allowing or 
disallowing group movement within it, (b) academic structure and its dynamics of legitimizing and de-legitimizing the content and the form of the curricula, and (c) historical factors and their dynamics of transferring or holding on to types of knowledge from the vantage point of a certain geographic location.

\section{How Would these Studies Help Us Think of the Future of Social Sciences and the Humanities?}

I started my essay on worldview and meaningful learning (Barazangi, 1993) before Middleton's book (1993) was published and before I was fully immersed in feminist studies. This essay provides the background for thinking about the issues discussed by both Middleton (1993) and hooks [sic] (1994). Though the essay was published in 1993, I originally wrote it in 1990, at the time when some academics in the US, such as Diane Ravitch and Arthur Schlesinger, Jr. were rebuking the multicultural history curriculum, especially as AfroAmericans, Native Americans, and other hyphenated Americans were re-mapping the field to redesign a NYS history curriculum for secondary education, and some Cornellians were involved. At that time also, the Religious Right movement was emphasizing the Judeo-Christian foundations of American education while different religious groups, particularly Muslims, were founding their own schools. Meanwhile the English-Only movement was denouncing bilingualism as divisive and blaming it for school failure among Hispanics. My assessment then was that arguments against multiculturalism blinded "mainstream" educators and policy-makers to realizing the instructional equity that such perspectives were bringing to both the pre- and post-secondary curricula even for the "mainstream" population. Such perspectives bring back to our attention John Dewey's (1909, quoted in Barazangi, 1993:84) emphasis that education should be the business of the people. The arguments against multiculturalism also blinded the 
mainstream policy-makers from recognizing the richness that such perspectives were bringing to the curricula. In retrospect, I also see the education reform movement of the 1980s and the universities' claim to diversity by adding some ethnic studies as having missed a golden opportunity that could have brought social sciences and the humanities together in an interactive pedagogy. That is, instead of changing their dichotomized paradigms, each of these fields turned inward, searching for strategies to patch their curricula with what I call "window-dressing approach to multiculturalism" and add-on materials. Meanwhile, the physical and biological sciences, though for different reasons, have captured the opportunity for interdisciplinary research and pedagogy. Why?

Ironically, feminist and women's studies programs were trapped in this separateness and inwardness even when such programs were leading the interdisciplinary movement (Tobias, 2000:36). As if it were not bad enough that feminist studies became divided by the existing ideologies--liberalism, radicalism, and socialism--as Middleton eloquently summarizes in her essay (1993: 38-43), women's studies programs further isolated themselves from activism in the struggle to gain legitimacy in academia. Theoretical grounding--those of social sciences or the humanities--became the new battlegrounds, and, effectively speaking, the movement toward interdisciplinary and multi-perspectives came to a halt. As a result, even women's studies curricula that were intended to be inclusive became, knowingly or unknowingly, exclusive and, at times, divisive as the voices of class, race, ethnicity, and geographic location became louder. This exclusiveness became more pronounced as the arguments for universal women's rights were introduced. The mistake of the post-World War II social scientists and humanists was repeated. Despite the rich literature resulting from feminist attempts to understand women and gender, most of these attempts were made within the existing discourse of the various 
disciplines, and the focus on the "self" or the "other" as the problem did not change either. Furthermore, the pedagogy became so abstract that women's studies began losing touch with the real issues that feminists teachers and learners were facing.

Sue Middleton discusses not only the major theoretical shifts within the disciplines of women's studies and sociology of education, but she also emphasizes the impact of school and university restructuring that affected both "the context and the content of our teaching and research." She adds, "the economics and politics of the New Right have not only shaped our material circumstances but have also become the objects of our academic inquires." (p.1) Though the New Right movement in New Zealand was rebuking the inclusion of the Maori and immigrant groups and women knowledge as part of sociology and education curricula, its historical connection and implications are not separate from other New Right movements in every other society, particularly in the Western hemisphere. Middleton cites the literature that was produced in Europe and America to argue against the individualism of the New Right and how antithetical it was to collectivist notions of social justice or equity.

I happened to read some of the literature that Middleton cites (Apple, 1986, Arnowitz \& Giroux, 1985) as a student of curriculum and instruction, while also reading reports such as the 1983 US Commission on Excellence in Education, “A Nation at Risk” and Allan Bloom's The Closing of the American Mind. The irony is that, although New Zealand feminism was being liberated from its European and American ancestors, European and American feminists were trying to cover new grounds in the fight between universal feminism and cultural sensitivity. At this juncture, curricular exclusiveness was being translated into social nationalistic and ethnic exclusiveness, and feminist and women's studies, for example, were reduced on social grounds to the women's rape as the weapon of ethnic cleansing or to the abortion battles. But, it was not 
until US revisionist policies of affirmative action and social welfare started making an impact on low socio-economic and single mothers that feminist movements started to feel the impact of this exclusiveness locally and beyond the color or cultural divides.

Bell hooks' [sic] Engaged Pedagogy (1994: Chapter 1), written at this peculiar time, especially when the forces of the American New Right were pitting one cultural group against another, analyzes this divide. Even when neither teachers nor students were ready to transgress these boundaries and intersect the liberating concepts of Afro-American and feminist studies, bell hooks [sic] reminds us, "many students still seek to enter feminist classrooms because they continue to believe that there, more than any other place in the academy, they will have an opportunity to experience education as the practice of freedom.” (1994:15)

\section{What Was the Process that Determined the Philosophy, Methodology and Content of these Studies?}

The theme of Middleton's book is built on the interaction of identity and knowledge, or as Sandra Harding (Is Science Multicultural; 1998:7-8) put it, the interaction of "science" and cultures. Similarly, I argue that the nature of this interaction either produces meaningful learning that is followed by action (in the form of change in conception and practice) or it could alienate the learner in the pluralistic education system (eliminating the goal of liberal education as being the business of the people) (Barazangi, 1993: 84-86). In parallel with my emphasis on the philosophical assumptions and their implications for meaningful learning, Middleton emphasizes life histories and bell hooks [sic] emphasizes education itself as the liberating process. Hooks' practice of freedom preempts her meaning of engaged pedagogy and is not a consequence of it. Can we, therefore, eliminate the social categories (minorities, disadvantaged, voiceless, colored, etc.) and the humanities categories (pre-and post-colonialism, modernism, third-world, etc.) that 
dominated these sciences to arrive at an organized way to make changes, as bell hooks [sic] challenges her students and us to do, in the practice of the curriculum?

\section{Who Were the Agents That Have Generated and Disseminated This Dichotomized Sciences?}

I define education as the process of conceptual and attitudinal change that may lead to social change, and curriculum as the course of action toward such change (Barazangi, 1993). Since this change requires an individual's identification with a worldview in a particular discourse, I argue that analyzing each element of the curriculum separately only within historical or contemporary context would only bring us back to the "old" discourse of the "superior culture," or superior group of people, or superior field of study that dictates the discourse in gathering and disseminating knowledge. Middleton provides a process toward realizing the learner's own knowledge by narrating the life history of her research and teaching, as well as the life histories of some of her colleagues and students, bell hooks [sic] through the voice of Maelinda, emphasizes that we would be misguided to act as though we have the luxury to consider these voices or leave them. So, what is the next step?

\section{Why Do We Need an Alternative Process?}

I address the learner's knowledge at the metacognitive level, as I relate the psychology to the philosophy of knowledge within the ontological view of knowledge and morality (Barazangi, 1993). I further propose that we search for what makes it possible for the learner to regain participation in understanding the particular subject matter whether in a single discipline or within an interdisciplinary setting. This autonomous participation means that a learner will make sense of the material on his/her own, without the meaning being controlled by interpretive 
sources, including the point of view of the instructor. Such autonomy is a pre-requisite to the cognitive and moral process of learning that will achieve change in conception, attitude, and practice of the curriculum (Barazangi, 2000, 1997). The learner's ability to achieve such an autonomous moral, intellectual and realistic state is the first step toward constructive, meaningful learning and action. It is this meaningful learning, and not mere acquisition of cognitive and moral skills, that may lead to a civic learning environment and to an egalitarian social practice of the democracy (Barazangi, 1998, 1996). The consequences of such curricular outcomes can be far more powerful than a mere liberal, progressive education, or mere liberal feminism, because they could alter the discourse through which the multitude of world views have been wrongly explained as merely multiple representations of voices or mere additions of diverse histories.

The intention of Middleton's book is to emphasize the core issues in educating the woman and the relevance of these issues to contemporary discussions of women and of the curriculum beyond the discipline of women's studies and sociology of education, and beyond cultural boundaries of area and minority studies. But more importantly, her book deconstructs the myth that there is a separation between the curriculum, for example, in "Western civilization" and "area studies," as if these areas of the world did not influence the development of Western civilization into the "Enlightenment" paradigm, or as if the rest of the world has not been the recipient of the modern technologies of the West. Even when these technologies are exported without their scientific foundations, they are not quite free of the condescending Orientals' worldview. 


\section{Who Might be the Agents of Re-Charting and Implementing the Course of Study?}

As the three authors look at the paradigm of critiquing the same discipline, women's education, in different contexts, and its discourse within a course that was supposed to represent that particular discipline, the exercise become too harsh to be tolerated, let alone accepted by the "guardians" of "academic integrity and freedom of expression," and of civil liberties and the freedom of religion act. Neither present departments nor colleges at Cornell, for instance, are willing to see the long-range goal and the in-depth, self-assessment and presuppositions that a student in such a course will be encountering. Perhaps, they see such a goal as threatening and, therefore, resent it. This resentment might be because of the fear of actually changing not only the learners' self-assessment of their own prior knowledge of the subjects, but that these learners might question the "authority" in the respective disciplines. ${ }^{2}$ Thus, the focus by curriculum committees is still on distribution requirements while diversity remains relegated mainly to the human resources administration.

\section{When it Would be Possible to Claim the Legitimacy of an Alternative Process?}

Beginning with selection of the reading material for the course, Middleton answers. But, she adds, one would still have to prepare her teaching in a conventionally "academic" manner, whatever that may mean, and yet at the same time present the contemporary feminists views and other concomitant views with regard to women's education and sociology of education.

Meanwhile, such an instructor is expected to be innovative in the teaching method as well as in the content of a course on feminist views on education, while using the conventional didactic, positivist means of "liberal" education and "the requirement" of the particular cross-

\footnotetext{
${ }^{2}$ See Barazangi, 1999, analysis of the BOCES teachers being in the same position, fearing a change in "authority."
} 
listed discipline. I ask: "How could such a teaching challenge the present discourse of women's education, while using the traditional dogmatic way of teaching?" (Barazangi, 1999) Without challenging the discourse of the discipline, both in schools and universities (Al-Faruqi, 1998), and without challenging present views with regard to woman's emancipation and human rights, (Barazangi, 2000, 1997), there could be no innovation.

\section{Conclusions}

In summary, I bring to the forefront the fact that what might seem to be a great opportunity for cultural group inclusion might, in the long run, be a trap by the larger social structure to maintain the status quo. Such a trap results from not changing the philosophy of mapping knowledge and its pedagogy, not because different cultural knowledge does not fit well with one another, nor is it a matter of including females or minority groups in the process.

This reminds me of a similar trap that appeared during the 10th century curricular development process in the Muslim Community-State. The disciplines that were taught in the early Madrasah (the higher learning model that preceded the resident college of Europe) did not have rigid boundaries, nor was the state involved in monitoring the content. The content and the course of study were negotiated between the disciple and the mentor, even when each came from different ideological, cultural and social backgrounds (Stanton, 1990: 18-19, 37-42). Yet as soon as the educational institutions became the tool of political rivalries, contents and boundaries were dictated in order to limit access to the opposing points of view, and creativity was reduced to whose requirements should be enforced, or how dogmatic a curriculum should be (Barazangi, 1995:20-24). 


\section{References Cited}

Apple, Michael, Teachers and texts: A Political Economy of Class and Gender Relations in Education, New York: Routledge \& Kegan Paul, 1986.

Aronowitz, Stanley \& Henry Giroux, Education under Siege : The Conservative, Liberal, and Radical Debate Over Schooling, South Hadley, Mass.: Bergin \& Garvey, 1985.

Barazangi, Nimat Hafez, "Muslim Women's Islamic Higher Learning as a Human Right: Theory and Practice," in Gisela Webb (ed), Windows of Faith: Muslim Women Scholar-Activists in North America, Syracuse: Syracuse University Press, 2000, pp. 22-47.

Female Adults Learners?" The Language and Literacy Spectrum. A Journal of The New York State Reading Association., Spring, 1999, 9: 2-16.

, “The Equilibrium of Islamic Education: Has Muslim Women's Education Preserved the Religion? in Nimat Hafez Barazangi, Guest Editor, Religion and Education, Winter 1998, 25, 1\& 2: 5-19.

Action Plan, in Muslim Women and the Politics of Participation: Beijing Platform, Mahnaz Afkhami and Erika Friedl (eds.), Syracuse University Press, 1997, pp. 43-57.

-------------------, "Vicegerency and Gender Justice in Islam,” in Nimat Hafez Barazangi, M. Raquibuz Zaman, and Omar Afzal (eds.), Islamic Identity and the Struggle for Justice, The University Press of Florida, 1996, pp. 77-94.

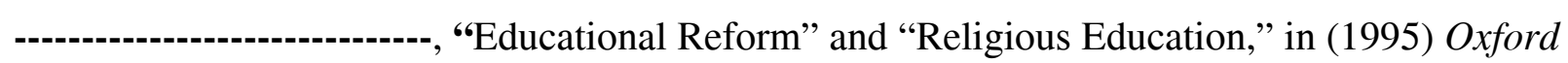
Encyclopedia of the Modern Islamic World. Oxford University Press, New York, Volume I: Pp. 407-420.

-, "Worldview, Meaningful Learning and Pluralistic Education: The Islamic Perspective", in Religion and Public Education, Winter1993, 20, 1, 2 \& 3: 84-98.

Bloom, Allan, The Closing of the American Mind, New York: Simon and Schuster, 1987.

Al-Faruqi, Maysam, "From Orientalism to Islamic Studies," in Religion \& Education: Journal of The National Council of Religion and Public Education, Winter 1998, 25, 1\&2: 20-29.

Harding, Sandra, Is science multicultural? : Postcolonialisms, Feminisms, and Epistemologies, Bloomington, Ind.: Indiana University Press, 1998.

hooks, bell, "Engaged Pedagogy" and "Feminist Thinking" in her Teaching to Transgress: Education as the Practice of Freedom, New York: Routledge, 1994. 
Middleton, Sue, "The Sociology of Women's Education as Discourse" in Sue Middleton Educating Feminists: Life Histories and Pedagogy, New York: Teachers College, Columbia University, 1993.

Stanton, Charles Michael, Higher Learning in Islam. Savage, MD: Rowman \& Littlefield, 1990.

Tobias, Sheila (Cornell University), "Beginning in the 1960s," in Florence Howe (ed.), Testimony From Thirty Founding Mothers: The Women's Studies History Series: Volume One. New York: The Feminist Press at the City University of New York, 2000: 29-38.

United States, National Commission on Excellence in Education A Nation at Risk: the Imperative for Educational Reform : a report to the nation and the Secretary of Education, United States Department of Education. Washington, D.C.: The Commission, 1983. 


\section{Appendix}

This paper was presented at the:

Institute for European Studies

The Future of the Social Studies and the Humanities in Corporate Universities

Curricula, Exclusions, Inclusions, and Voice

Facilitator: Nimat Hafez Barazangi (391 Uris Hall, Ithaca, NY 14853)

E-mail: nhb2@cornell.edu

Women's Studies Program and the Cornell Participatory Action Research Network

Monday, October 30, 2000

4:30-6:00pm

Room 201, Andrew D. White House

This session explores some of the issues of the curriculum, what is included, what is not, what is voiced, and what is not as part of our broader attempts to understand what issues are taken up and what issues are ignored in contemporary universities.

The readings include the following and a full set will be available to you in 120 Uris Hall by noon, Monday, October 23, through the campus mail by calling 255-7592, and in the Anthropology/Sociology Study, 401 Olin Library.

- Sue Middleton, "The Sociology of Women's Education as Discourse" in her Educating Feminists: Life Histories and Pedagogy, 1993.

- bell hooks, "Engaged Pedagogy" and Feminist Thinking" from her Teaching to Transgress: Education as the Practice of Freedom, 1994.

- Nimat Hafez Barazangi, "Worldview, Meaningful Learning and Pluralistic Education; The Islamic Perspective", in Religion and Public Education, 1993. 